\title{
Quality-differentiated Auditors, Block-holders and Monitoring Mechanisms
}

\author{
Rachael Oluyemisi Arowolo* and Ayoib Che-Ahmad \\ Tunku Puteri Intan Safinaz School of Accountancy, College of Business, Universiti Utara Malaysia, Kedah, \\ Malaysia
}

\begin{abstract}
Many companies are closing down after the global economic meltdown of 2008 that involved Enron. The biggest problem for such business failures as identified by practitioners and academicians is information asymmetry existing in the relationship of the managements with the shareholders. This study seeks to investigate how monitoring mechanisms influence the block-holders in 111 Nigerian non-financial listed companies to resolve this problem. The study also investigates the mediating effect of the quality-differentiated auditors on the relationship between block-holders and monitoring mechanisms. The investigation adopted quantitative analysis using Stata to test related hypotheses. The findings indicate that the blockholders significantly influence monitoring mechanisms. The results also reveal that quality-differentiated auditors positively affect monitoring mechanisms and that it significantly explains the relationship between blockholders and monitoring mechanisms. Thus, this paper adds to knowledge on the subject of monitoring mechanisms and its scopes (directorship, internal and external auditing). These findings have policy implications for the board of directors to execute their monitoring responsibilities and guide them in external audit type selection. The findings also provide policy suggestions for both the internal and external auditors. The results can also be beneficial for the regulatory agencies and government to further review the guidelines for corporate governance. The paper adds to knowledge in Sub-Saharan Africa, especially, Nigeria by examining a mediating effect to expose the relationship between block-holders and monitoring mechanisms, which are not clear or exist in the previous studies.
\end{abstract}

Keywords: Monitoring mechanisms, quality-differentiated auditors, institutional block-holders, individual block-holders, agency problems, Nigeria

JEL Classification: M4, M40, M41, M42, M48, M49

Paper Type: Research Paper

*Corresponding author: E-mail: aroldaot@gmail.com 


\section{INTRODUCTION}

Investors are finding it more necessary to monitor the managements to ensure that their interests are well protected. The relentless business failures after the global economic collapse involving Enron, Worldcom and others compel this desire (Al-Janadi, Rahman, \& Omar, 2013). The investors are the principals while management of the companies is the agents (Jensen \& Meckling, 1976). The existence and level of information asymmetry, opportunistic attitudes of the management and the largest shareholders (Freeman, 1994) and weak corporate governance practices (Ikpefan \& Ojeka, 2013) determine the type of relationship between the two parties. Agency theory clarifies the problems existing between the two parties (Fama \& Jensen, 1983). Shareholders monitor their agents adopting monitoring mechanisms (Huson, Parrino, \& Starks, 2001) that allow maximum transparency and accountability to limit the agency problems (Jensen \& Meckling, 1976; Kao, Chiou, \& Chen 2004). Monitoring mechanisms help to align the interests of the managers and the shareholders (Azim, 2012) and induce management to maintain shareholders' interests (Shleifer \& Vishny, 1997).

Companies' performance in a country contributes to the status of the economy of the country and its gross domestic products (GDP). Hence governments, practitioners, and academicians are concerned with corporate monitoring mechanisms. Governments, regulatory agents, and companies have therefore been continually reviewing their codes of corporate governance (Huson et al., 2001). Also, academicians have been examining issues related to monitoring mechanisms and corporate governance (Fodio, Ibikunle, \& Oba, 2013; Banerjee, Couzoff, \& Pawlina, 2012; Liu, Uchida, \& Yang, 2012; MohamadNor, Shafie \& Wan-Hussin, 2010; Mustapha \& Che-Ahmad, 2009).

Despite government and regulatory agents unrelenting efforts to reform corporate governance codes and prior literature on corporate governance and monitoring mechanisms, business failures such as bankruptcies, corporate mergers, inadequate disclosure in financial reports and loss of shareholders' trusts, and confidence persist in global and national economy (Waweru, 2014; Fodio et al., 2013; Akinbuli \& Kelilume, 2013; Cadbury, 1992). The effects transform to currency depreciation, increased unemployment, poor education, bad roads and transportation, criminality and corruption, substantial reduction in stock values, increased child abuse, rampant poverty, poor health facilities, power failures, insecurity and declining income (Hylton, 2011; Habbash, 2013; Akanle, Adebayo, \& Adetayo, 2014). These incidents suggest the need for more empirical examination of corporate monitoring mechanisms.

There is extant literature on monitoring mechanisms. However, most of the studies are effected in transiting and developed countries like Malaysia, U.K, and U.S, (Banerjee et al., 2012; Liu et al., 2012; Mohamad-Nor Shafie \& Wan-Hussin, 2010; Mustapha \& Che-Ahmad, 2009). Also, many of these studies do not address the general monitoring mechanisms (directorship, internal and external auditing), but one or two of its antecedents. Some literature is just on directorship only (Latif, Kamardin, Mohd, \& Adam, 2013; Gamba \& Goldstein, 2009;). Some are only on internal auditing (Moorthy, Seetharaman, Mohamed, Gopalan, \& San, 2011; Soh \& Martinov-Bennie, 2011;). Some others are on external auditing alone (Bachlechner, Thalmann, \& Manhart, 2014; Chow, 2012;). Very few examine directorship and internal auditing or directorship and external auditing while others investigate internal and external auditing (Pizzini, Lin, Vargus, \&

Ziegenfuss, 2014; Sarens, De Beelde, \& Everaert, 2009; Chen \& Zhou, 2007). Only two of the extant literature treated total monitoring mechanisms in their studies (Mustapha \& Che-Ahmad, 2009; Anderson, Francis, \& Stokes, 1993).

There is a dearth of literature on monitoring mechanisms in Sub-Saharan Africa, Nigeria in particular. There are few studies on directorship (Uadiale, 2010), internal and 
external auditing (Zare, Khedri, \& Farzanfar, 2013), and external auditing (Ogiedu \& Izedonmi, 2013; Adeyemi \& Fagbemi, 2010) in Nigeria. To the best of the knowledge of the researchers, none of the researchers examine the aggregate monitoring mechanisms (directorship, internal and external auditing) in their studies.

The extant literature on monitoring mechanisms that are with moderating or mediating variables are very few (Omri, Becuwe, \& Mathe, 2014; Triana, Miller, \& Trzebiatowski, 2013). None of these examine quality-differentiated auditor as a moderating or mediating variable.

In Nigeria, the serious business failures, drops in stock values, and bankruptcy consequential to weak monitoring mechanisms and weakness in enforcing a code of corporate governance have been a centre of attraction (Enofe, Mgbame, Aronmwan, \& Ogbeide, 2013; Adeyemi \& Fagbemi, 2010; Babatunde \& Olaniran, 2009). The concern for the seemingly battered economy in Nigeria, reviewed code of corporate governance notwithstanding motivates this study. Other motivations for this study are the drought of literature on monitoring mechanisms in Nigeria, scarce literature empirically examining combined monitoring mechanisms as well as an indirect effect on relationships of organizational attributes and monitoring mechanisms. This study, therefore, empirically tests the mediating effect of the quality-differentiated auditors on the relationship between the block-holders and monitoring mechanisms (directorship, internal and external auditing) in Nigerian non-financial listed companies.

To the best of the knowledge of the researchers, this is the first study to empirically investigate the mediating effect of quality-differentiated auditors on the relationships between block-holders and monitoring mechanisms (directorship, internal and external auditing). It is also the first study to examine total monitoring mechanisms (directorship, internal and external auditing) in the relationships between block-holders and monitoring mechanisms in Sub-Saharan African, Nigeria in particular. The next section of this study is concerned with literature review followed by hypotheses development, sections on methodology, results and conclusion.

\section{LITERATURE REVIEW}

Monitoring mechanisms denote different things to different individuals (Kao, Chiou, \& Chen 2004; Shleifer \& Vishny, 1997; Azim, 2012). However, irrespective of the different definitions, the objective of these tools to resolve agency problems remains the same. Al-Janadi et al. (2013) in Saudi Arabia, examine corporate governance mechanisms relationship with voluntary disclosure. The study defines monitoring mechanisms as the process by which companies provide adequate and satisfactory information through financial statements to protect the shareholders' interests. The study of Bachlechner et al. (2014), on how auditing service providers relate to cross-organizational settings used data from 2 face-to-face and 14 telephone interviews. Monitoring mechanisms, according to the study are the tools by which companies identify and satisfy the information needs of the shareholders through adequate controls. Banerjee et al. (2012) in U.S, examine the effect of external monitoring and managerial entrenchment on corporate cash holdings. The study defines monitoring mechanisms as tools that companies are using to reduce the quantity of company assets that management can expropriate.

The study of Babatunde and Olaniran (2009) investigates how internal and external mechanisms affects a company's governance and performance in Nigeria. According to the study, monitoring mechanisms are the governance tools that companies employ to preclude managers from engaging activities that may not optimize shareholders' values. Pizzini et al. (2014) examine the quality and contributions of internal audit function to 
audit delays. The study defines monitoring mechanisms as the means of inhibiting material weaknesses in the internal control and financial reporting of a company.

This paper explains the mediating effect of quality-differentiated auditors on the relationships between block-holders and monitoring mechanisms using agency theory. The rationale for this is that agency theory is designed to proffer solutions to agency problems, which is the main root of monitoring (Jensen \& Meckling, 1976). Signalling theory is adopted in addition to agency theory because of the signals that qualitydifferentiated auditors give to investors and public at large in respect of monitoring and fraudulent characters dominating the modern day business entities. With these different definitions in existing literature on monitoring mechanisms, this study investigates the mediating effect of the quality-differentiated auditors on the relationships between the block-holders and monitoring mechanisms (directorship, internal and external auditing).

\section{HYPOTHESES DEVELOPMENT}

\subsection{Block-Holders}

The study of Azim (2012), examines how corporate governance mechanisms documents impact on company performance. The study claims that if the ownership of a company is dispersed control by shareholders may be weak. Also, it suggests that ownership concentration strengthens monitoring by block-holders for reduction of management's opportunistic attitude. It claims that block-holders through proxy-voting and direct relationship with the management regulate the distribution of power between the management and shareholders. Habbash (2013) examines the effect of the audit committee and block-holders on agency problems using 350 UK large firms. It claims that companies with high block-holders have fewer agency problems due to the separation between control and ownership. The study further claims that the agency problems change from management-shareholders' to majority-minority shareholders' conflict especially with the managerial or family owner block-holder. Furthermore, it claims that high block-holders' presence on the board of directors regulates the effectiveness of monitoring by the audit committee. Thus, the presence of high blockholders suggests a decrease in the board of directors and audit committee's independence. Extant literature categorizes block-holders differently (Azim, 2012). This study considers two categories of block-holders as in 3.1.1 and 3.1.2.

\subsubsection{Institutional Block-Holders}

According to agency theory institutional block-holders help to reduce the opportunistic behavior of the management. The existing literature shows that institutional blockholders are likely to demand more monitoring as their shareholding increases (Waweru, 2014; Liu, 2012; Kao, Chiou, \& Chen, 2004; Shleifer \& Vishny, 1997). The study of Kao, Chiou, \& Chen (2004) examines the roles of monitoring mechanisms in respect of collateralized shares. The study reveals that institutional block-holders help to reduce agency problems effectively. Liu (2012), examines how board monitoring and management are contracting influence earnings management. The study finds that institutional block-holders with long-term bearings help to ease earnings management. The study of Liu et al. (2012) on how corporate governance and firm value relate during the global financial crisis finds that institutional block-shareholders limit financial constraints and expropriation problems. Omri et al. (2014) examine how the ownership structure and innovative behavior relate and investigate if board composition mediates the relationship in Tunisia. The study illustrates that institutional block-holders positively correlate to the number of outside directors on a board of directors. Likewise, the study 
suggests that institutional block-holders relate to independent directors and innovative behavior of manager significantly.

The institutional block-holders are, therefore, expected to uphold the independence of the board since more non-executive and independent directors will be on the board of directors. Similarly, institutional block-holders will request for more monitoring to safeguard their interests. They hold large shares; they have various interests in several security investments and are also with more information about the company to drive their demand for monitoring. Their demand for more monitoring engenders the alignment of the interests of the management and shareholders to reduce agency problems. The request for more monitoring necessitates more costs for implementing adequate monitoring. This study, therefore, expects that:

$\mathbf{H}_{1} \quad$ Institutional block-holders associate positively with the demand for monitoring mechanisms (directorship, internal and external auditing).

$\mathbf{H}_{2}$ Institutional block-holders associate positively with the demand for a directorship as a monitoring mechanism.

$\mathbf{H}_{3} \quad$ Institutional block-holders associate positively with the demand for internal auditing as a monitoring mechanism.

$\mathbf{H}_{4}$ Institutional block-holders associate positively with the demand for external auditing as a monitoring mechanism.

\subsubsection{Individual Block-Holders}

Most of the existing literature on block-holders either fail to test individual block-holders or lump both the individual and institutional block-holders together regardless of the difference between the two (Connelly, Hoskisson, Tihanyi, \& Certo, 2010). The study further claims that individual block-holders are treated in some cases as insider owners. The study of Haniffa and Hudaib (2006) examines corporate governance structure and performance of Malaysian listed companies. The study in consistency with the claim of Haniffa and Hudaib (2006) suggests that individual shareholders are often insiders like CEOs or family owners or top management related parties. It further argues that the controlling block-holders may expropriate the company's assets. Ali and Lesage (2013) investigate to know if auditors are engaged as monitoring mechanisms for mitigation of agency conflicts resulting from different controlling shareholders in France. The findings of the study confirm the results of Haniffa and Hudaib (2006) that only block-holders are likely to expropriate company assets. Eng and Mak (2003) examine ownership structure and board composition impact on voluntary disclosure. The study shows that blockholders do not relate to the level of disclosure.

Based on the above discussion, ownership may not be separated from control as demanded by agency theory for good corporate governance if the controlling shareholder is an individual block-holder. However, this study differs in its investigation because the data collected for the study does not portray that individual block-holders are insider-owners as suggested by Haniffa and Hudaib (2006). The study considers individual block-holders as outsiders. It is, therefore, expected that individual blockholders' demand for monitoring though not equally strong as the institutional blockholders because they are not as influential as the institutional block-holders. Therefore, this study predicts that:

$\mathbf{H}_{5} \quad$ Individual block-holders associate positively with the demand for monitoring mechanisms (directorship, internal and external auditing).

$\mathbf{H}_{6} \quad$ Individual block-holders associate positively with the demand for directorship as a monitoring mechanism

$\mathbf{H}_{7}$ Individual block-holders associate positively with the demand for internal auditing as a monitoring mechanism. 
$\mathbf{H}_{8} \quad$ Individual block-holders associate positively with the demand for external auditing as a monitoring mechanism.

\subsection{Quality-Differentiated Auditors}

Our study examines the mediating effect of the quality-differentiated auditors on the relationship between the block-holders and monitoring mechanisms. There are extant literature on quality-differentiated auditors (Francis \& Wilson, 1988; Palmrose, 1988; Defond, Francis, \& Wong, 2000; Che-ahmad \& Abidin, 2001; Nasser, Wahid, Nazri \& Hudaib, 2006; Willekens \& Achmadi, 2003; Che-Ahmad, Houghton, \& Yusof, 2006). The emergence of large companies and complexity of such companies warrants need for detection and reporting of breaches in the accounting system of the companies (Ferguson, Pinnuck, \& Skinner, 2013; DeAngelo, 1981). The studies claim that this need for high-quality financial reports led to the emergence of quality-differentiated auditors. Hence, the emergence of audit firms with quality-differentiated auditors is a response to the demand of the clients (Craswell \& Taylor, 1991). It is expected that the organizational attribute, block-holders affects quality-differentiated auditors. The study, therefore, predicts that:

$\mathbf{H}_{\mathbf{9}} \quad$ Institutional block-holders associate positively with the demand for qualitydifferentiated auditors.

$\mathbf{H}_{10}$ Individual block-holders associate positively with the demand qualitydifferentiated auditors.

Likewise, it is expected that quality-differentiated auditors affect monitoring mechanisms and that a quality-differentiated auditor mediates between block-holders and monitoring mechanisms. The study, therefore, predicts that:

$\mathbf{H}_{11}$ Quality-differentiated auditors mediate the relationship between institutional block-holders and the demand for monitoring mechanisms (directorship, internal and external auditing).

$\mathbf{H}_{12}$ Quality-differentiated auditors mediate the relationship between institutional block-holders and the demand for a directorship as a monitoring mechanism.

$\mathbf{H}_{13}$ Quality-differentiated auditors mediate the relationship between institutional block-holders and the demand for internal auditing as a monitoring mechanism.

$\mathbf{H}_{14}$ Quality-differentiated auditors mediate the relationship between institutional block-holders and the demand for external auditing as a monitoring mechanism.

$\mathrm{H}_{15}$ Quality-differentiated auditors mediate the relationship between individual block-holders and the demand for monitoring mechanisms (directorship, internal and external auditing).

$\mathbf{H}_{16}$ Quality-differentiated auditors mediate the relationship between individual block-holders and the demand for a directorship as a monitoring mechanism.

$\mathbf{H}_{17}$ Quality-differentiated auditors mediate the relationship between individual block-holders and the demand for internal auditing as a monitoring mechanism.

$\mathbf{H}_{18}$ Quality-differentiated auditors mediate the relationship between individual block-holders and the demand for external auditing as a monitoring mechanism. 


\section{METHODOLOGY}

\subsection{Sample}

The study used 111 non-financial Nigerian listed companies using data from 2010 to 2012 annual reports and other data collected through questionnaires. The annual reports lack information in respect of the internal auditing. Hence, the study applied the questionnaires to obtain information needed for internal auditing. There were no similar annual reports for 6 of the 117 questionnaires collected.

\subsection{Measurement}

\subsubsection{Dependent Variable}

The dependent variable in this paper is the monitoring mechanism. It has three dimensions (directorship, internal and external auditing) and its measurement is the total costs of the three dimensions. It is the summation of the audit costs (internal and external) plus non-executive directors' remuneration.

\subsubsection{Mediating Variable}

The mediating variable, the quality-differentiated auditor, is binary coded as 1 if the auditor for the company is a big-4 and 2 if a non-big-4.

\subsubsection{Independent Variables}

Block-ownership is the independent variable in this study. Institutional block-holders as an independent variable is measured as a proportion of the institutional block shareholders stock to the company's issued share capital. Individual block-holders as a variable is measured as a proportion of the individual block shareholders stock to the issued share capital of the company.

\subsubsection{Control Variables}

The control variables in this paper are industry and complexity. The industry is a binary coded variable scored as 1 for manufacturing and 0 for services. Complexity's measurement is the numbers of a company's subsidiaries, headquarter company inclusive.

\subsubsection{Panel Data Models}

The models for the empirical tests are as follows:

$M C_{i t}=\alpha_{i t}+\beta_{1} I N S B_{i t}+\beta_{2} I N D B_{i t}+\beta_{3} I N D_{i t}+\beta_{4} C Y_{i t}+\mu_{i t}+\varepsilon_{i t}$

equation 1

(Equation 1 regressing dependent variable on independent variables)

$\mathrm{QDA}_{i t}=\alpha_{i t}+\beta_{1} I N S B_{i t}+\beta_{2} I N D B_{i t}+\beta_{3} I N D_{i t}+\beta_{4} C Y_{i t}+\mu_{i t}+\varepsilon_{i t}$

(Equation 2 regressing mediating variable on independent variables)

equation 2

$M C_{i t}=\alpha_{i t}+\beta_{1} I N S B_{i t}+\beta_{2} I N D B_{i t}+\beta_{3} I N D_{i t}+\beta_{4} C Y_{i t}+\beta_{4} Q_{D A} A_{i t}+\mu_{i t}+\varepsilon_{i t}$

equation 3

(Equation 3 regressing dependent variable on both independent and mediating variables)
Where:
$\mathrm{MC}=$ Monitoring Cost
INSB $=$ Institutional Block-holders
INDB = Individual Block-holders
IND = Industry 
$\begin{array}{lll}C Y & = & \text { Complexity } \\ \text { QDA } & = & \text { Quality-differentiated Auditors }\end{array}$

\section{RESULTS}

In this study, the researchers effected data cleaning; tested for multicollinearity, respondent bias, autocorrelation, heteroscedasticity, and normality. All tests suggest that the models meet the minimum requirement for multivariate analysis. An exception to these results is the presence of autocorrelation which cannot be eliminated in a panel data. Likewise, the F-tests for the models are statistically significant $(p<0.0000)$. The independent variables, institutional and individual block-holders are respectively with mean values of $47 \%$ and $8 \%$. Their minimum scores are 0 because some companies are with no detail information on block-holders. Their maximum scores are respectively $97.35 \%$ and $87 \%$. Table 1 presents the results on collinearity and multicollinearity, while Table 2 presents the results of variance inflation factors (VIF) and tolerance of the study. The variables in this study are free from collinearity and multicollinearity as all the values are less than 0.9 , the VIF is 1.01 , which is below the threshold of 5 and tolerance are more than 0.2 .

Table 1. Variance Inflation Factors (VIF)

\begin{tabular}{lrr}
\hline Variable & VIF & $\mathbf{1 / V I F}$ \\
\hline Institutional Block-holders & 1.40 & 0.713 \\
Individual Block-holders & 1.42 & 0.704 \\
Industry & 1.04 & 0.959 \\
Complexity & 1.04 & 0.966 \\
Mean VIF & 1.23 & \\
\hline
\end{tabular}

Table 2. Pearson Correlation

\begin{tabular}{lccccc}
\hline Variables & $\begin{array}{c}\text { Monitoring } \\
\text { Mechanisms }\end{array}$ & $\begin{array}{c}\text { Institutional } \\
\text { Block-holders }\end{array}$ & $\begin{array}{c}\text { Individual Block- } \\
\text { holders }\end{array}$ & Industry & Complexity \\
\hline Monitoring & 1 & & & & \\
Mechanisms & 1 & & & & \\
Institutional & 0.0081 & & & & \\
Block-holders & & & & & \\
Individual Block- & -0.1312 & -0.5128 & & & \\
holders & 0.093 & 0.0911 & -0.2025 & 1 & 1 \\
Industry & 0.6367 & -0.1443 & -0.0229 & 0.0241 & 1 \\
Complexity & & & &
\end{tabular}

The study examines the mediating effect of quality-differentiated auditors on the relationship between the block-holders and monitoring mechanisms (directorship, internal and external auditing) in Nigerian non-financial listed companies. We used panel-corrected standard errors (PCSEs) regression for the direct relationship between the organizational attributes (institutional and individual block-holders) and monitoring mechanisms (C-Path). According to Bailey and Katz (2011), PCSEs regression is robust in nature and proficient in correcting heteroscedasticity and autocorrelation. Table $3 a$ presents results of the regressions ran using Stata. We tested hypothesis 1 to know if block-holders have any influence on the demand for monitoring mechanisms solving equation 1. The results indicate that the relationship between the institutional blockholders and aggregate monitoring mechanisms is significantly positive $(\beta=A 156,056$, $z=2.39)$.

The results also provide evidence that the relationships between the institutional block-holders and internal auditing $(\beta=N 51,665.23, z=10.13)$ and external auditing $(\beta=\mathrm{N} 192,136.5, \quad z=5.02)$ are also significantly positive. However, the result of the 
relationship between institutional block-holders and directorship ( $\beta=\mathrm{N} 87,745.47, z=2.92$ ) is significantly negative. The study finds a significant negative relationship between individual block-holders and monitoring mechanisms $(\beta=A 364,034.4, z=8.03)$. It also provides evidence of a significant negative relationship between individual block-holders and the dimensions of monitoring mechanisms [directorship $(\beta=\mathrm{N} 278,538,4.54)$, and external auditing $(\beta=\mathbb{N} 96,697.79, z=7.71)$. It shows a positive relationship between individual block-holders and internal auditing $(\beta=N 11,201.4, z=0.72)$ but with no statistical evidence. The study illustrates significant positive relationships between the control variables, (industry and complexity) and monitoring mechanisms as well as all the three dimensions, directorship, internal and external auditing.

Table 3a. Equation 1 Using Panel-Corrected Standard Errors (PCSE)

\begin{tabular}{lrrrr}
\hline Variables & Coef. & Std. Err. & $\mathbf{Z}$ & P>Z \\
\hline Monitoring Mechanisms & & & & \\
Institutional Block-holdes & 0.156 & 0.065 & 2.39 & 0.017 \\
Individual Block-holdes & -0.364 & 0.045 & -8.03 & 0.000 \\
Industry & 13.400 & 2.245 & 5.96 & 0.000 \\
Complexity & 12.300 & 0.516 & 23.77 & 0.000 \\
$\quad$ cons & -1.478 & 2.432 & -0.61 & 0.543 \\
\hline Directorship & & & & \\
Institutional Block-holdes & -0.088 & 0.030 & -2.92 & 0.003 \\
Individual Block-holdes & -0.279 & 0.061 & -4.54 & 0.000 \\
Industry & 3.741 & 0.999 & 3.74 & 0.000 \\
Complexity & 7.915 & 0.494 & 16.01 & 0.000 \\
cons & -1.809 & 2.055 & -0.88 & 0.379 \\
\hline Internal Auditing & & & & \\
Institutional Block-holdes & 0.052 & 0.005 & 10.13 & 0.000 \\
Individual Block-holdes & 0.011 & 0.016 & 0.72 & 0.473 \\
Industry & 2.982 & 0.372 & 8.02 & 0.000 \\
Complexity & 0.353 & 0.024 & 14.72 & 0.000 \\
cons & 12.200 & 0.654 & 18.62 & 0.000 \\
\hline External Auditing & & & & \\
Institutional Block-holdes & 0.192 & 0.038 & 5.02 & 0.000 \\
Individual Block-holdes & -0.097 & 0.013 & -7.71 & 0.000 \\
Industry & 6.666 & 1.009 & 6.61 & 0.000 \\
Complexity & 3.998 & 0.576 & 6.95 & 0.000 \\
cons & -11.800 & 2.765 & -4.29 & 0.000 \\
\hline Quality-differentiated Auditors & & & & \\
Institutional Block-holdes & -0.003 & 0.000 & -6.84 & 0.000 \\
Individual Block-holdes & -0.008 & 0.001 & -11.14 & 0.000 \\
Industry & 0.075 & 0.007 & 10.64 & 0.000 \\
Complexity & 0.022 & 0.001 & 16.22 & 0.000 \\
cons & 0.655 & 0.024 & 27.72 & 0.000 \\
\hline Quality-differentiated Auditors & & & & \\
Institutional Block-holdes & -0.016 & 0.005 & -2.92 & 0.004 \\
Individual Block-holdes & -0.036 & 0.009 & -3.85 & 0 \\
Industry & 0.348 & 0.365 & 0.95 & 0.34 \\
Complexity & 0.150 & 0.045 & 3.32 & 0.001 \\
$\quad$ cons & 0.601 & 0.490 & 1.23 & 0.22 \\
\hline & & & &
\end{tabular}

We tested hypothesis 2 using equation 2 for a direct relationship between organizational attributes (institutional block-holders, individual block-holders) and quality-differentiated auditors (A Path). The results of this regression are shown in Tables $3 \mathrm{~b}$ and $3 \mathrm{c}$ using panel-corrected standard errors (PCSEs) and logistics. Both institutional and individual block-holders have a significant negative relationship with quality-differentiated auditors. The beta coefficient for institutional block-holders is 003 with z-value of 6.84 while individual block-holders is with a beta value of 0.008 and z-value of 11.14 (all negative) 
running regression by PCSEs. When regression was run using logistics because of the binary nature of quality-differentiated auditors, the beta coefficient for institutional blockholders and individual block-holders are 0.016 and 0.037 and z-value of 2.92 and 3.85 (all negative) respectively.

The two control variables, industry, and complexity are both positively significant with a beta of 0.022 and 0.655 and $z$-value of 10.64 and 16.22 respectively using PCSEs. However, industry $(\beta=0.348, z=0.95)$ is not statistically relevant using logistic regression, while complexity $(\beta=0.15, z=3.32)$ remains positively significant.

Table 3b. Equation 2 Using Panel-Corrected Standard Errors (PCSE)

\begin{tabular}{lccrc}
\hline Quality-differentiated Auditors & Coef. & Std. Err. & z & P>z \\
\hline Institutional Block-holders & -0.003 & 0.000 & -6.84 & 0.000 \\
Individual Block-holders & -0.008 & 0.001 & -11.14 & 0.000 \\
Industry & 0.075 & 0.007 & 10.64 & 0.000 \\
Complexity & 0.022 & 0.001 & 16.22 & 0.000 \\
cons & 0.655 & 0.024 & 27.72 & 0.000 \\
\hline
\end{tabular}

Table 3c. Equation 2 Using logistics

\begin{tabular}{lcrrr}
\hline Quality-differentiated Auditors & Coef. & Std. Err. & z & P>z \\
\hline Institutional Block-holders & -0.016 & 0.005 & -2.92 & 0.004 \\
Individual Block-holders & -0.036 & 0.009 & -3.85 & 0.000 \\
Industry & 0.348 & 0.365 & 0.95 & 0.340 \\
Complexity & 0.150 & 0.045 & 3.32 & 0.001 \\
cons & 0.601 & 0.490 & 1.23 & 0.220 \\
\hline
\end{tabular}

The study used binary-mediation to test hypothesis 3 solving equation 3 (b-Path and Total Effect). For b-path, Table 4a shows that quality-differentiated auditors significantly and positively relate to monitoring mechanisms and its three dimensions (directorship, internal and external auditing).

Table 4a. Binary-mediation

\begin{tabular}{|c|c|c|c|c|c|c|c|c|}
\hline Variables & $\begin{array}{c}\text { Monitoring } \\
\text { Mechanisms }\end{array}$ & $\begin{array}{l}\text { Director- } \\
\text { ship }\end{array}$ & $\begin{array}{l}\text { Internal } \\
\text { Auditing }\end{array}$ & $\begin{array}{l}\text { External } \\
\text { Auditing }\end{array}$ & $\begin{array}{c}\text { Monitoring } \\
\text { Mechanisms }\end{array}$ & $\begin{array}{l}\text { Director- } \\
\text { ship }\end{array}$ & $\begin{array}{c}\text { Internal } \\
\text { Auditing }\end{array}$ & $\begin{array}{l}\text { External } \\
\text { Auditing }\end{array}$ \\
\hline \multicolumn{9}{|l|}{ Model A } \\
\hline $\begin{array}{l}\text { Quality- } \\
\text { differentiated }\end{array}$ & $46.420^{* * *}$ & $23.010^{* * *}$ & $4.326^{* * *}$ & $19.080^{* * *}$ & $43.940^{* * *}$ & $? 2.790^{* * *}$ & $3.978^{* * *}$ & $17.180^{* * *}$ \\
\hline Auditors & $(8.050)$ & (5.927) & $(1.281)$ & $(2.562)$ & (8.126) & $(6.012)$ & (1.305) & (2.617) \\
\hline Institutional & 0.082 & -0.137 & $0.050^{*}$ & $0.169^{* * *}$ & & & & \\
\hline $\begin{array}{l}\text { Block- } \\
\text { holders }\end{array}$ & & $(0.107)$ & $(0.023)$ & $(0.046)$ & & & & \\
\hline $\begin{array}{l}\text { Individual } \\
\text { Block- } \\
\text { holders }\end{array}$ & & & & & $\begin{array}{l}-0.392 \\
(0.254)\end{array}$ & $\begin{array}{l}-0.139 \\
(0.188)\end{array}$ & $\begin{array}{l}-0.027 \\
(0.041)\end{array}$ & $\begin{array}{c}-0.226^{* * *} \\
(0.082)\end{array}$ \\
\hline Constant & $\begin{array}{c}27.350^{\star \star *} \\
(9.462)\end{array}$ & $\begin{array}{l}16.180^{*} \\
(6.967)\end{array}$ & $\begin{array}{c}13.740^{* * *} \\
(1.506)\end{array}$ & $\begin{array}{l}-2.575 \\
(3.012)\end{array}$ & $\begin{array}{c}35.970^{* * *} \\
(6.773)\end{array}$ & $\begin{array}{l}10.990^{*} \\
(5.011)\end{array}$ & $\begin{array}{c}16.540^{* * *} \\
(1.088)\end{array}$ & $\begin{array}{c}8.443^{* * *} \\
(2.181)\end{array}$ \\
\hline Observations & 333 & 333 & 333 & 333 & 333 & 333 & 333 & 333 \\
\hline R-squared & 0.092 & 0.050 & 0.044 & 0.165 & 0.097 & 0.047 & 0.032 & 0.151 \\
\hline \multicolumn{9}{|l|}{ Model B } \\
\hline $\begin{array}{l}\text { Quality- } \\
\text { differentiated }\end{array}$ & $45.200^{* * *}$ & $23.260^{* * *}$ & $3.969^{* * *}$ & $17.970^{\star * *}$ & $27.140^{\star \star *}$ & $10.730^{*}$ & $3.786^{\star * *}$ & $12.630^{* * *}$ \\
\hline Auditors & (8.044) & $(5.947)$ & $(1.287)$ & (2.602) & (6.469) & $(5.000)$ & $(1.312)$ & $(2.172)$ \\
\hline Industry & $\begin{array}{c}15.800 \\
(12.350)\end{array}$ & $\begin{array}{c}5.061 \\
(9.129)\end{array}$ & $\begin{array}{c}2.845 \\
(1.976)\end{array}$ & $\begin{array}{l}7.896^{*} \\
(3.994)\end{array}$ & & & & \\
\hline Complexity & & & & & $\begin{array}{c}11.470^{* * *} \\
(0.808)\end{array}$ & $\begin{array}{c}7.759^{\star * *} \\
(0.624)\end{array}$ & $\begin{array}{c}0.209 \\
(0.164)\end{array}$ & $\begin{array}{c}3.503^{* * *} \\
(0.271)\end{array}$ \\
\hline Constant & $\begin{array}{c}17.980 \\
(12.140)\end{array}$ & $\begin{array}{c}5.078 \\
(8.975)\end{array}$ & $\begin{array}{c}13.800^{* * *} \\
(1.943)\end{array}$ & $\begin{array}{l}-0.890 \\
(3.927)\end{array}$ & $\begin{array}{c}1.758 \\
(5.252)\end{array}$ & $\begin{array}{l}10.680^{* * *} \\
(4.059)\end{array}$ & $\begin{array}{c}15.680^{* * *} \\
(1.065)\end{array}$ & $\begin{array}{c}-3.235^{\star *} \\
(1.763)\end{array}$ \\
\hline Observations & 333 & 333 & 333 & 333 & 333 & 333 & 333 & 333 \\
\hline R-squared & 0.095 & 0.047 & 0036 & 0.142 & 0.436 & 0350 & 0035 & 0423 \\
\hline
\end{tabular}

NOTE: ${ }^{* * *}$ significant at $1 \%$ level; ${ }^{* *}$ significant at $5 \%$ level; ${ }^{*}$ significant at $10 \%$ level; $n=333 ; \mathrm{SN}=111$ 
The result suggests that quality-differentiated auditor is a possible mediator between block-holders and monitoring mechanisms including each of its antecedents. Its beta coefficient ranges between $\$ 3.786 \mathrm{~m}$ and $\$ 46.42 \mathrm{~m}$, while its $\mathrm{t}$-value ranges between 2.15 and 7.45. A variable must affect the dependent variable before it can mediate between the dependent variable and an independent variable (Baron \& Kenny, 1986). The result in this paper meets this requirement.

Table 4b presents the bootstrap analysis on the mediating effect of qualitydifferentiated auditors (QDA) on the relationship between block-holders and monitoring mechanisms (directorship, internal and external auditing). The result demonstrates that the mediating relationship (indirect effect) is significant as the confidential interval for each of the variables in the model includes no zero. Hence, QDA serves as a mediator between block-holders (institutional and individual) and monitoring mechanisms (directorship, internal and external auditing). It also acts as a mediator between the control variables (industry and complexity) and monitoring mechanisms (directorship, internal and external auditing).

Table 4b. Bootstrap Coefficient, Direct and Indirect Effects (Institutional Block-holders, Individual Block-holders, Monitoring Mechanisms - Directorship, Internal, and External Auditing.

\begin{tabular}{|c|c|c|c|c|c|c|c|c|c|c|c|c|}
\hline \multirow{2}{*}{ Variables- } & \multicolumn{3}{|c|}{$\begin{array}{c}\text { Institutional Block- } \\
\text { holders }\end{array}$} & \multicolumn{3}{|c|}{$\begin{array}{c}\text { Individual } \\
\text { Blockholders }\end{array}$} & \multicolumn{3}{|c|}{ Industry } & \multicolumn{3}{|c|}{ Complexity } \\
\hline & $\begin{array}{l}\text { Coef.I } \\
\text { Stder }\end{array}$ & \multicolumn{2}{|c|}{$\begin{array}{l}\text { [95\% Conf. } \\
\text { Interval] }\end{array}$} & $\begin{array}{l}\text { Coef.I } \\
\text { Stder }\end{array}$ & \multicolumn{2}{|c|}{$\begin{array}{c}\text { [95\% Conf. } \\
\text { Interval] }\end{array}$} & $\begin{array}{l}\text { Coef.I } \\
\text { Stder }\end{array}$ & \multicolumn{2}{|c|}{$\begin{array}{l}\text { [95\% Conf. } \\
\text { Interval] }\end{array}$} & $\begin{array}{l}\text { Coef.I } \\
\text { Stder }\end{array}$ & \multicolumn{2}{|c|}{$\begin{array}{l}\text { [95\% Conf. } \\
\text { Interval] }\end{array}$} \\
\hline \multicolumn{13}{|c|}{ Monitoring Mechanisms } \\
\hline Indirect & -0.024 & -0.063 & 0.013 & $-0.055^{*}$ & -0.108 & -0.017 & 0.028 & -0.005 & 0.066 & $0.056^{\star * *}$ & 0.032 & 0.087 \\
\hline & -0.019 & -0.064 & 0.012 & $(0.023)$ & -0.107 & -0.015 & -0.018 & -0.008 & 0.064 & $(0.014)$ & 0.032 & 0.087 \\
\hline Total & -0.024 & -0.063 & 0.013 & $-0.055^{\star}$ & -0.108 & -0.017 & 0.028 & -0.005 & 0.066 & $0.056^{* * *}$ & 0.032 & 0.087 \\
\hline Indirect & -0.019 & -0.064 & 0.012 & $(0.023)$ & -0.107 & -0.015 & -0.018 & -0.008 & 0.064 & $(0.014)$ & 0.032 & 0.087 \\
\hline Direct & 0.030 & -0.085 & 0.177 & $-0.082^{*}$ & -0.162 & 0.010 & $0.067^{* * *}$ & 0.027 & 0.103 & $0.600^{* * *}$ & 0.396 & 0.735 \\
\hline Effect & -0.065 & -0.102 & 0.159 & $(0.041)$ & -0.162 & 0.010 & $(0.019)$ & 0.028 & 0.103 & $(0.087)$ & 0.388 & 0.732 \\
\hline Total & 0.005 & -0.109 & 0.154 & $-0.137^{* * *}$ & -0.217 & -0.056 & $0.095^{\star * *}$ & 0.046 & 0.138 & $0.656^{\star * *}$ & 0.455 & 0.783 \\
\hline Effect & -0.068 & -0.114 & 0.146 & $(0.042)$ & -0.213 & -0.051 & $(0.022)$ & 0.045 & 0.137 & $(0.084)$ & 0.455 & 0.783 \\
\hline \multicolumn{13}{|c|}{ Directorship } \\
\hline \multirow[t]{2}{*}{ Indirect } & -0.017 & -0.046 & 0.007 & $-0.040^{\star * *}$ & -0.073 & -0.015 & 0.02 & -0.005 & 0.046 & $0.031^{* * *}$ & 0.010 & 0.056 \\
\hline & -0.013 & -0.048 & 0.007 & $(0.015)$ & -0.076 & -0.017 & -0.013 & -0.002 & 0.048 & $(0.012)$ & 0.012 & 0.059 \\
\hline Total & -0.017 & -0.046 & 0.007 & $-0.040^{* * *}$ & -0.073 & -0.015 & 0.02 & -0.005 & 0.046 & $0.031^{* * *}$ & 0.010 & 0.056 \\
\hline Indirect & -0.013 & -0.048 & 0.007 & $(0.015)$ & -0.076 & -0.017 & -0.013 & -0.002 & 0.048 & $(0.012)$ & 0.012 & 0.059 \\
\hline Direct & -0.069 & -0.162 & 0.054 & -0.040 & -0.118 & 0.036 & 0.03 & -0.016 & 0.067 & $0.564^{* * *}$ & 0.310 & 0.699 \\
\hline Effect & -0.055 & -0.162 & 0.056 & $(0.041)$ & -0.111 & 0.049 & -0.022 & -0.014 & 0.074 & $(0.101)$ & 0.279 & 0.696 \\
\hline Total & -0.085 & -0.178 & 0.032 & $-0.080^{* *}$ & -0.161 & 0.000 & $0.050^{*}$ & -0.004 & 0.092 & $0.594^{* * *}$ & 0.350 & 0.726 \\
\hline Effect & -0.055 & -0.179 & 0.030 & $(0.041)$ & -0.152 & 0.008 & -0.024 & 0.004 & 0.098 & $(0.097)$ & 0.308 & 0.721 \\
\hline \multicolumn{13}{|c|}{ Internal Auditing } \\
\hline \multirow[t]{2}{*}{ Indirect } & -0.015 & -0.041 & 0.007 & $-0.032^{*}$ & -0.071 & -0.007 & 0.016 & -0.004 & 0.043 & $0.050^{*}$ & 0.011 & 0.096 \\
\hline & -0.012 & -0.044 & 0.004 & $(0.016)$ & -0.076 & -0.008 & $(0.012)$ & -0.003 & 0.046 & $(0.022)$ & 0.018 & 0.104 \\
\hline Total & -0.015 & -0.041 & 0.007 & $-0.032^{*}$ & -0.071 & -0.007 & 0.016 & -0.004 & 0.043 & $0.050^{*}$ & 0.011 & 0.096 \\
\hline Indirect & -0.012 & -0.044 & 0.004 & $(0.016)$ & -0.076 & -0.008 & $(0.012)$ & -0.003 & 0.046 & $(0.022)$ & 0.018 & 0.104 \\
\hline Direct & $0.116^{*}$ & 0.021 & 0.208 & -0.037 & -0.141 & 0.065 & $0.078^{* *}$ & -0.001 & 0.158 & 0.070 & -0.044 & 0.181 \\
\hline Effect & -0.050 & 0.026 & 0.208 & $(0.052)$ & -0.137 & 0.072 & $(0.042)$ & -0.001 & 0.158 & $(0.060)$ & -0.038 & 0.186 \\
\hline Total & $0.102^{*}$ & 0.009 & 0.195 & -0.070 & -0.167 & 0.026 & $0.094^{*}$ & 0.013 & 0.179 & $0.120^{*}$ & 0.004 & 0.227 \\
\hline Effect & -0.05 & 0.011 & 0.197 & $(0.049)$ & -0.167 & 0.026 & $(0.043)$ & 0.014 & 0.180 & (0.058) & 0.009 & 0.231 \\
\hline \multicolumn{13}{|c|}{ External Auditing } \\
\hline \multirow[t]{2}{*}{ Indirect } & -0.030 & -0.077 & 0.014 & $-0.065^{\star \star \star}$ & -0.113 & -0.021 & 0.034 & -0.015 & 0.076 & $0.078^{\star \star \star}$ & 0.052 & 0.108 \\
\hline & $(0.024)$ & -0.078 & 0.014 & $(0.024)$ & -0.113 & -0.021 & $(0.023)$ & -0.015 & 0.076 & $(0.015)$ & & 0.116 \\
\hline Total & -0.030 & -0.077 & 0.014 & $-0.065^{\star * *}$ & -0.113 & -0.021 & 0.034 & -0.015 & 0.076 & $0.078^{* \star *}$ & 0.052 & 0.108 \\
\hline Indirect & $(0.024)$ & -0.078 & 0.014 & $(0.024)$ & -0.113 & -0.021 & $(0.023)$ & -0.015 & 0.076 & $(0.015)$ & 0.056 & 0.116 \\
\hline Direct & $0.184^{* * *}$ & 0.078 & 0.295 & $-0.142^{* * *}$ & -0.186 & -0.102 & $0.101^{* * *}$ & 0.063 & 0.141 & $0.552^{* * *}$ & 0.370 & 0.699 \\
\hline Effect & $(0.055)$ & 0.078 & 0.296 & $(0.021)$ & -0.179 & -0.097 & $(0.021)$ & 0.056 & 0.139 & $(0.086)$ & 0.388 & 0.714 \\
\hline Total & $0.154^{*}$ & 0.043 & 0.274 & $-0.207^{* * *}$ & * -0.256 & -0.169 & $0.135^{\star * *}$ & 0.097 & 0.174 & $0.630^{\star * *}$ & 0.437 & 0.770 \\
\hline Effect & $(0.061)$ & 0.043 & 0.274 & $(0.023)$ & -0.250 & -0.165 & $(0.020)$ & 0.090 & 0.171 & $(0.085)$ & 0.453 & 0.784 \\
\hline
\end{tabular}


The result conforms to extant literature that institutional block-holders help to resolve agency problems and so will demand more monitoring (Kao, Chiou, \& Chen, 2004; Liu et al., 2012). Also, Mustapha and Che-Ahmad (2013), claim that institutional blockholders demand more monitoring costs with an increase in their shareholding. Following the conformational analysis of the findings to the studies of Mohd-Saleh, Rahman, and Hassan (2009), Kao, Chiou, and Chen (2002), Mustapha and Che-Ahmad (2013), Liu et al. (2012) a company is likely to protect the interests of its institutional block-holders. Hence, it will demand more monitoring. The result is also consistent with agency theory that institutional block-holders help to minimize the opportunistic behaviors of management through the demand for more monitoring.

Many of the institutional block-holders in Nigeria are foreign owners, government, and banks. They demand more monitoring as their shares increase. Institutional blockholders, therefore, influence monitoring mechanisms positively and significantly.

Hope (2013) claims that a company is likely to hire a Big 4 auditor as its ownership concentration decreases. Likewise, it conforms with the claim of Desender, Aguilera, Crespi, \& Garcia-Cestona (2013), that the audit scope of quality-differentiated auditors will enforce directorship monitoring. This paper conforms to the studies of Hope (2013) and Desender et al. (2013) by providing evidence that institutional block-holders contribute to the variations in the demand for quality-differentiated auditors. All these extant literature put together are consistent with the findings in this study that institutional block-holders affect monitoring mechanisms, affect quality-differentiated auditors and that quality-differentiated auditors affect monitoring mechanisms. Hence, qualitydifferentiated auditors mediate the relationship between institutional block-holders and monitoring mechanisms.

The result for individual block-holders, though in the opposite direction of prediction conforms to the findings in the prior literature (Ali \& Lesage, 2013; Haniffa \& Hudaib, 2006; Eng \& Mak, 2003). Interests of individual block-holders are more of self-benefits, hence, the claim of Mustapha and Che-Ahmad (2013) that individual block-holders' demand for monitoring costs decreases with increase in their shareholding. Hence, individual block-holders affect monitoring mechanisms but negatively. Thus, this study provides evidence that individual block-holders in Nigerian companies investigated are likely related to the top management or they are management or family owners. The incentive for them to monitor management because of the size of their stockholding is deterred by their relationship with the top management. Individual block-holders are often few and are unlike institutional block-holders are with less information. They are inhibited from exercising their rights because of insufficient information, financial illiteracy and ignorance of their rights. According to Bennedsen and Wolfenzon (2000), they are also with insufficient votes to control the activities of the company. Shareholders' associations are, therefore, emerging in countries, even in Nigeria to fortify the votes for controlling the company to protect their interests. However, individual block-holders in Nigeria are very scanty. Hence, their association may not be so powerful to exercise their right and guarantee adequate monitoring of the companies.

Similarly, the findings provide evidence that individual block-holders negatively contribute to the variations in the demand for quality-differentiated auditors. Since they are likely related to or are the top management or family owners of the company; they are likely motivated to expropriate company's asset. Hence, their demand for qualitydifferentiated auditors will be lesser for fear of being exposed. Moreso, the quality of the auditing of the quality-differentiated auditors, signals to the individual slock-holders a probability of exposing the management with the ability to serve as a forensic auditor, detecting and reporting fraud in the form of any misappropriation of company assets. 
Since individual block-holders significantly affect both monitoring mechanisms and quality-differentiated auditors and quality-differentiated auditors also positively affect monitoring mechanisms, while the bootstrap results demonstrate significant mediation in all the relationships, quality-differentiated auditors are likely to mediate between individual block-holders and monitoring mechanisms.

\section{CONCLUSION}

The study adds to the literature on block ownership, agency conflicts, monitoring mechanisms and quality-differentiated auditors. The primary contributions of this paper are that (1) block-holders significantly affect monitoring mechanism and qualitydifferentiated auditors, (2) quality-differentiated auditors also have a significant positive relationship with monitoring mechanisms, and (3) also have a mediating effect on the relationship between block-holders (institutional and individual) and monitoring mechanisms. Likewise, the control variables, industry, and complexity relate to monitoring mechanisms and quality-differentiated auditors significantly. Qualitydifferentiated auditors also mediate in the relationship between the control variables, industry and complexity and monitoring mechanisms. The primary contribution of this study to knowledge is the introduction of quality-differentiated auditors as a mediating variable in the relationship between block-holders and monitoring mechanisms. These findings are of importance for the investors, the board of directors, auditors, government, and the regulatory agents in respect of the protection of minority shareholders. This study is restricted to non-financial listed companies. Future studies may, therefore, consider extending the study to cover financial listed companies as well.

\section{REFERENCES}

Adeyemi, S. B., \& Fagbemi, T. O. (2010). Audit Quality, Corporate Governance and Firm Characteristics in Nigeria. International Journal of Business and Management, 5(5), 169.

Akanle, O., Adebayo, K., \& Adetayo, O. (2014). Fuel Subsidy in Nigeria: Contexts of Governance and Social Protest. International Journal of Sociology and Social Policy, 34(1/2), 88-106.

Akinbuli, S. F., \& Kelilume, I. (2013). The Effects of Mergers and Acquisition on Corporate Growth and Profitability: Evidence from Nigeria. Global Journal of Business Research, 7(1), 43-58.

Ali, C. B., \& Lesage, C. (2013). Audit pricing and nature of controlling shareholders: Evidence from France. China Journal of Accounting Research, 6(1), 21-34.

Al-Janadi, Y., Rahman, R. A., \& Omar, N. H. (2013). Corporate Governance Mechanisms and Voluntary Disclosure in Saudi Arabia. Research Journal of Finance and Accounting, 4(4), 2536.

Anderson, D., Francis, J. R., \& Stokes, D. J. (1994). Auditing, Directorships and the Demand for Monitoring. Journal of Accounting and Public Policy, 12(4), 353-375.

Azim, M. I. (2012). Corporate Governance Mechanisms and Their Impact on Company Performance: A Structural Equation Model Analysis. Australian Journal of Management, 0312896212451032.

Babatunde, M. A., \& Olaniran, O. (2009). The Effects of Internal and External Mechanisms on Governance and Performance of Corporate Firms in Nigeria. Corporate Ownership \& Control, 7(2), 330-344.

Bachlechner, D., Thalmann, S., \& Manhart, M. (2014). Auditing Service Providers: Supporting Auditors in Cross-Organizational Settings. Managerial Auditing Journal, 29(4), 286-303.

Bailey, D., \& Katz, J. N. (2011). Implementing Panel Corrected Standard Errors in R: The PCSE Package. Journal of Statistical Software, 42(CS1), 1-11.

Banerjee, S., Couzoff, P., \& Pawlina, G. (2012). External Monitoring, Managerial Entrenchment and Corporate Cash Holdings. 
Baron, R. M., \& Kenny, D. A. (1986). The Moderator-Mediator Variable Distinction in Social Psychological Research: Conceptual, Strategic, and Statistical Considerations. Journal of Personality and Social Psychology, 51(6), 1173-1182.

Bennedsen, M., \& Wolfenzon, D. (2000). The Balance of Power in Closely Held Corporations. Journal of Financial Economics, 58(1), 113-139.

Cadbury, A. (1992). Cadbury Report: The Financial Aspects of Corporate Governance. Tech report, HMG, London.

Che-Ahmad, A., \& Abidin, S. (2001). Auditor Industry Specialisation, Brand Name Auditors, and Financial Reporting Lag. Working Paper, Universiti Utara Malaysia.

Chen, K. Y., \& Zhou, J. (2007). Audit committee, board characteristics, and Auditor Switch Decisions by Andersen's Clients. Contemporary Accounting Research, 24(4), 1085-1117.

Chow, C. W. (1982). The Demand for External Auditing: Size, Debt, and Ownership Influences. Accounting Review, 272-291.

Connelly, B. L., Hoskisson, R. E., Tihanyi, L., \& Certo, S. T. (2010). Ownership as a form of corporate governance. Journal of Management Studies, 47(8), 1561-1589.

Craswell, A. T., \& Taylor, S. L. (1991). The Market Structure of Auditing in Australia: The Role of Industry Specialization. Research in Accounting Regulation, 5(1), 55-77.

DeAngelo, L. E. (1981). Auditor Size and Audit Quality. Journal of Accounting and Economics, 3(3), 183-199.

DeFond, M. L., Francis, J. R., \& Wong, T. J. (2000). Auditor Industry Specialization and Market Segmentation: Evidence from Hong Kong. Auditing: A Journal of Practice \& Theory, 19(1), 49-66.

Desender, K. A., Aguilera, R. V., Crespi, R., \& Garcĺa-cestona, M. (2013). When Does Ownership Matter? Board Characteristics and Behavior. Strategic Management Journal, 34(7), 823-842.

Eng, L. L., \& Mak, Y. T. (2003). Corporate Governance and Voluntary Disclosure. Journal of Accounting and Public Policy, 22(4), 325-345.

Enofe, A. O., Mgbame, C. O., Aronmwan, E. J., \& Ogbeide, I. E. (2013). Audit Reasonableness Expectation Gap: Users' Perception in Nigeria. International Journal of Business and Social Research, 3(3), 154-163.

Fama, E. F., \& Jensen, M. C. (1983). Separation of Ownership and Control. The Journal of Law \& Economics, 26(2), 301-325.

Ferguson, C., Pinnuck, M., \& Skinner, D. (2013). Audit Pricing and the Emergence of the Big 4: Evidence from Australia. University of Melbourne.

Fodio, M. I., Ibikunle, J., \& Oba, V. C. (2013). Corporate Governance Mechanisms and Reported Earnings Quality in Listed Nigerian Insurance Firms. International Journal of Finance and Accounting, 2(5), 279-286.

Francis, J. R., \& Wilson, E. R. (1988). Auditor Changes: A Joint Test of Theories Relating to Agency Costs and Auditor Differentiation. Accounting Review, 663-682.

Freeman, R. E. (1994). The Politics of Stakeholder Theory: Some Future Directions. Business Ethics Quarterly, 4(04), 409-421.

Gamba, M., \& Goldstein, A. (2009). The Gender Dimension of Business Elites: Italian Women Directors since 1934. Journal of Modern Italian Studies, 14(2), 199-225.

Habbash, M. (2013). Earnings Management, Audit Committee Effectiveness and the Role of Blockholders Ownership: Evidence from UK Large Firms. International Journal of Business Governance and Ethics, 8(2), 155-180.

Haniffa, R., \& Hudaib, M. (2006). Corporate governance structure and performance of Malaysian listed companies. Journal of Business Finance \& Accounting, 33(7-8), 1034-1062.

Hope, O. K. (2013). Large shareholders and accounting research. China Journal of Accounting Research, 6(1), 3-20.

Huson, M. R., Parrino, R., \& Starks, L. T. (2001). Internal Monitoring Mechanisms and CEO Turnover: A long-term perspective. The Journal of Finance, 56(6), 2265-2297.

Hylton, M. O. B. (2011). Combating Moral Hazard: The Case for Rationalizing Public Employee Benefits. Ind. L. Rev., 45, 413-482.

Ikpefan, O. A., \& Ojeka, S. (2013). Corporate Governance as a Tool for Curbing Bank Distress in Nigeria Deposit Money Bank: Empirical Evidence. Change and Leadership, (17), 22-38. 
Jensen, M. C., \& Meckling, W. H. (1976). Theory of the Firm: Managerial Behavior, Agency Costs, And Ownership Structure. Journal of Financial Economics, 3(4), 305-360.

Kao, L., Chiou, J. R., \& Chen, A. (2004). The Agency Problems, Firm Performance, and Monitoring Mechanisms: The Evidence From Collateralised Shares In Taiwan. Corporate Governance: An International Review, 12(3), 389-402.

Latif, R. A., Kamardin, H., Mohd, K. N. T., \& Adam, N. C. (2013). Multiple directorships, board characteristics and firm performance in Malaysia. Management, 3(2), 105-111.

Liu, C., Uchida, K., \& Yang, Y. (2012). Corporate governance and firm value during the global financial crisis: Evidence from China. International Review of Financial Analysis, 21, 70-80.

Liu, J. (2012). Board monitoring, management contracting and earnings management: evidence from ASX listed companies. International Journal of Economics and Finance, 4(12), 121-136.

Mohamad-Nor, M. N., Shafie, R. \&, \& Wan-Hussin, W. N. (2010). Corporate governance and audit report lag in Malaysia. Asian Academy of Management Journal of Accounting and Finance, 6(2), 57-84.

Mohd-Saleh, N., Rahman, C. A., \& Ridhuan, M. (2009). Ownership structure and intellectual capital performance in Malaysia. Asian Academy of Management Journal of Accounting and Finance, 5(1), 1-29.

Moorthy, M. K., Seetharaman, A., Mohamed, A. S. Z., Gopalan, M., \& San, L. H. (2011). The impact of information technology on internal auditing. African Journal of Business Management, 5(9), 3523-3539.

Mustapha, M., \& Che Ahmad, A. (2009). Organisational Attributes and Corporate Monitoring Mechanisms (Doctoral dissertation, Universiti Utara Malaysia).

Mustapha, M., \& Che Ahmad, A. (2013). Blockholders and corporate monitoring costs: evidence from Malaysia. International Journal of Economics and Management, 7(1), 28-44.

Nasser, A. T. A., Wahid, E. A, Nazri, S. N. F. S., \& Hudaib, M. (2006). Auditor-client relationship: the case of audit tenure and auditor switching in Malaysia. Managerial Auditing Journal, 21(7), 724-737.

Ogiedu, K. O., \& Izedonmi, F. I. (2013). Topology of Audit Agency/Audit Techniques and the Effectiveness of the Nigerian Supreme Audit Institution. Topology, 4(6), 193-204.

Omri, W., Becuwe, A., \& Mathe, J. C. (2014). Ownership structure and innovative behavior: Testing the mediatory role of board composition. Journal of Accounting in Emerging Economies, 4(2), 220-239.

Palmrose, Z. V. (1988). 1987 Competitive Manuscript Co-Winner: An analysis of auditor litigation and audit service quality. Accounting review, 55-73.

Pizzini, M., Lin, S., Vargus, M. E., \& Ziegenfuss, D. E. (2014). The impact of internal audit function quality and contribution on audit delay. Auditing: A Journal of Practice \& Theory, 34(1), 25-58.

Sarens, G., De Beelde, I., \& Everaert, P. (2009). Internal audit: A comfort provider to the audit committee. The British Accounting Review, 41(2), 90-106.

Shleifer, A., \& Vishny, R. W. (1997). A survey of corporate governance. The journal of finance, 52(2), 737-783.

Soh, D. S., \& Martinov-Bennie, N. (2011). The internal audit function: Perceptions of internal audit roles, effectiveness, and evaluation. Managerial Auditing Journal, 26(7), 605-622.

Triana, M. D. C., Miller, T. L., \& Trzebiatowski, T. M. (2013). The double-edged nature of board gender diversity: Diversity, firm performance, and the power of women directors as predictors of strategic change. Organization Science, 25(2), 609-632.

Uadiale, O. M. (2010). The impact of board structure on corporate financial performance in Nigeria. International Journal of Business and Management, 5(10), 155-166.

Waweru, N. (2014). Determinants of quality corporate governance in Sub-Saharan Africa: Evidence from Kenya and South Africa. Managerial Auditing Journal, 29(5), 455-485.

Willekens, M., \& Achmadi, C. (2003). Pricing and supplier concentration in the private client segment of the audit market: Market power or competition? The International Journal of Accounting, 38(4), 431-455.

Zare, R., Khedri, S., \& Farzanfar, F. (2013). Examining the Effect of Auditing Institution, Internal Auditing Department and Companies' Profitability on Voluntary Information Disclosure in 
Quality-differentiated Auditors, Block-holders and Monitoring Mechanisms

Tehran Stock Exchange. International Journal of Economy, Management, and Social Sciences, 2(9), 680-686. 